\title{
A QUALITATIVE STUDY TO ASSESS THE COMPETENCIES OF WOMEN LIVING IN FAIFA MOUNTAINS TO HELP MEN FOR WITHDRAWAL OF CHEWING KHAT HABIT; JAZAN REGION, SAUDI ARABIA
}

By

\author{
Anwar Makeen ${ }^{1}$, Amal Al-Faify ${ }^{2}$ and Sarah El-Reffaey ${ }^{3}$ \\ ${ }^{1}$ Assistant Professor of Community and Family Medicine, Faculty of Medicine, Jazan University, KSA \\ ${ }^{2}$ Senior Registrar of Family Medicine, Ministry of Health, Jazan, KSA \\ ${ }^{3}$ Professor of Forensic Medicine and Toxicology, Faculty of Medicine Jazan University, KSA
}

ABSTRACT

Introduction For ages; people in Faifa Mountains (Jazan region, Kingdome of Saudi Arabia) cultivate Khat tree and the men chew their leaves. Many adverse effects are documented among men chewing Khat for a long time especially on the central nervous system, heart and liver due to the action of sympathetic - like substances that Khat contains. Till today in Faifa; there is no effective intervention that could replace Khatchewing habit and leads to its withdrawal.

Objectives: The goal of this study is to assess the competencies of women in their families to help men in withdrawal of Khat- chewing habit. This will be examined through the specific objectives to investigate the knowledge, attitudes and behaviours of women towards Khat-chewing habit that practiced by men in their families.

Methodology: This research is designed to assess the competencies; knowledge, attitudes and behaviours of women in Faifa mountains towards Khat- chewing habit among the men in their families and its effect on the family social and economic status. It is performed according to qualitative research principles using in- depth interviews through semi- structured questionnaire. This study is performed on a purposive sample composed of 20 women above 15 years old having men chewing Khat in their families and residing in Faifa Mountains.

Results: The most prominent findings in this study are that $65 \%$ of the women believe that Chewing Khat is not forbidden. However, $95 \%$ of them are sure that there are adverse effects due to this habit summarized as liver and heart disease. Although $85 \%$ of the investigated women are looking for withdrawing this habit and described some interventions to stop this habit; $80 \%$ of them feel that they do not have a role in stopping this habit. Seventy percent of women believe that this habit neither affects the work, religious behaviour of men, the financial status of the family nor the social relationships. Ninety-five percent of women do not exert any effort to stop this habit for their men expecting the resistance of men. On the other side, $95 \%$ of them educate their children about the adverse effect of this habit as it is wrong to be practiced.

Conclusion: Although women realize the adverse effects of Khat chewing habit, they do not recognize it has any negative effect on their lives either socially or economically. However, they have a will to stop this habit among their men but do not exert a considerable effort for that, except giving some information to their children to avoid this habit. This may give place for further studies about how to stop the Khat chewing habit rather than influence of women on men in the Faifa Mountains

Keywords: Khat withdrawal, cognitive attitudes, affective attitudes, conative attitudes.

Corresponding author: Dr. Sarah El-Reffaey

Email:selreffaey@yahoo.com

\section{INTRODUCTION}

T he green tree of Khat was known in the Faifa mountains (Jazan region, Kingdom of Saudi Arabia) for ages. Locally, it is known as Khat, qat, and gat (Kalix and Branden 1985).

The mountains of Faifa, ocated in south west Saudi Arabia; east of Jazan enjoy moderate climate and temperatures throughout the year, which distinguishes it from the rest of the kingdom highlands. The Faifa mountains area is famous for its agricultural terraces and characterized by these heights of green flora that cover them. The Faifa Mountains are rising from the sea at about 7000 feet. An area, that encompasses nearly $600 \mathrm{Km}$, covers them with greenery types of plants, herbs, and flowers. It is known for its traditional heritage as expressed by many popular arts, folk proverbs, legends, judgement, and poetry. Twenty tribes and clans dwell this region with agriculture as their main industry where cereals, fruits, and aromatic plants are cultivated, of which is the Khat (Al Arabia NEWS, 2021).

The use of Khat (Catha edulis) is a major public health and social problem that is 
believed to be growing globally. The Khat chewing habit is prevalent in all areas of the Jazan region, Kingdom of Saudi Arabia. However, few studies have been conducted at the community level to investigate the Khat chewing habit in this area, (Mahfouz et al., 2015).

This plant is mainly cultivated in Africa and Arabian Peninsula. Those who use Khat chew the fresh leaves for pleasurable and stimulating effect. Khat is the leaves and young shoots of Catha edulis, of the family Celestraceae. Khat leaves contain psychoactive ingredients known as Cathinone, which is structurally and chemically similar to d-amphetamine, and Cathine, a milder form of Cathinone. Fresh leaves contain both ingredients; those left unrefrigerated beyond 48 hours would contain only Cathine which explains users' preference for fresh leaves as Cathinone, the most potent active principle of Khat, is chemically unstable (Abdelwahab et al., 2018).

Khat has a long history of use in social and cultural practices in the areas where it is grown and used to increase concentration and performance during trading, farming, academic and leisure activities. In its natural form, it is chewed and then kept in the cheek for several hours, which releases the stimulus trapped in the plant (Miller et al., 2019)

Moderate use reduces fatigue, increase functioning and socialization and reduces appetite. Chronic and heavy Khat use has been linked to symptoms of psychosis and paranoid ideation as well as risks to cardiovascular and periodontal health (Miretu et al., 2019).

In addition to its stimulant-like effects on the central nervous system, physical effects of using Khat include increased blood pressure, increased heart rate, slow pupil reaction to light and physical arousal. Long term Khat use increase physical stress on the body, especially on the heart. Khat users may be more likely diagnosed with the acute coronary syndrome, even without other cardiovascular risk factors. Khat may have a causative or worsening effect on stroke, myocardial infarction and heart failure, (Mega and Dabe, 2017).
Khat may also contribute to sever liver disease, although it appears that the liver may recover from damage following cessation, (NIDDKD, 2018).

A large proportion of the Jizani population is Khat chewers. There is a suggestion for the government and non-governmental organizations (NGOs) to design and strengthen community prevention programs to curb the high prevalence of Khat use as law enforcement alone is not enough to reduce the high prevalence of this deeply rooted habit among the Jazan population (Al Arabia NEWS, 2021).

Goal of the study:

The goal of this study is to assess the competencies of women living in Faifa Mountains to help men in withdrawal of Khat- chewing habit, Jazan region, Saudi Arabia

\section{Specific objectives of the study:}

To assess the competencies of women in Faifa region towards Khat -chewing habit among men in their families the following specific objectives are determined:

1-To assess women' knowledge about Khat use and its adverse effect

2-To identify women's attitudes regarding the effect of al Khat chewing habit among men; on the family, social and economic statues

3- To determine women's current behaviour towards this habit

\section{Methodology}

\section{Study design:}

This study has been conducted using the qualitative research principles (Andrews and Scott, 2013).

Study area:

The Faifa Mountains in Jazan governorate

\section{Study setting:}

The women were invited individually and separately by the researcher for the interviews. The interviews were conducted at a house of one of the participants in this study.

\section{Duration of study}

The study lasted for nine months (7/1434 $3 / 1435)$ and the interviews were conducted in period of 3 months $(8 / 1434-11 / 1434)$

Sample frame:

Women living in Faifa Mountains 


\section{Sample type:}

It is a purposive type of non-probability sample. Faifa women above 15-year-old in families having men chewing Khat at any social, economic, marital and educational statues who are available to the researcher (either relative or neighbor).

\section{Sample size:}

Twenty women (20) above 15 years having men in their families chewing khat are selected to be the sample for this qualitative research. The women are divided into 4 groups: (15-24 years), (25-34years), (3545years) and (above 45) with 5 women in each group.

\section{Study inclusion criteria:}

Females above 15 years old who have men in their families chewing khat (relative and neighbor to the researcher). Recording the interviews by a mobile recorder was the method of documenting the interviews then was transferred to the written form for analysis.

\section{Study exclusion criteria:}

Females less than 15 years old

Females who do not have men in their families chewing khat

- Females who refused to participate in the study

\section{Study tool:}

The semi structured guideline used for the indepth interviews and all conversations with women were in the Arabic language; the mother tongue. All the questions, conversations and statements are translated to the English language by the main supervisor. The guidelines included the following questions:

-Questions to determine the demographic data: including age, social status, single or married, number of children-number of family members, income of the family and ownership of a garden cultivating Khat trees

-Questions to determine knowledge about Khat chewing habit: included what do they Know about chewing Khat from the religious point of view? And do they know if Khat has adverse effects on health? And if so; what are they?

-Questions that pin down the existing attitudes: How do they feel when a man in their family chews the Khat? Do they want him to withdraw from this habit, and why? what ways do they think could help men in withdrawing from this habit and what are the expected challenges?, Do they prefer their husbands, sons or brothers to live in a city rather than in the Faifa region to withdraw from this habit ?, Do they encourage the continuous governmental order for removal of Khat tree, and why?, Do you believe that you have a role in the reduction/withdrawal of Khat-chewing habit, and why?, Could you influence the male member in your family to change any other behaviour, if not, who has an influence over him ?, Do you think that you can prevent your child or young brother from this habit?

-Questions that describe the behaviour of men chewing Khat according to women consideration; included: Does he use the natural Khat?, Does he use the Khat contaminated with insecticide?, Does Khat chewing habit affect the religious performance i.e. delaying prayer time?, Does it lead to oversleep ?, In what way does this habit influence your life ?, Is there any change on Khat's user's his health or behaviour?, How does this habit influence the financial status of the family ?, Where does he spend the time of chewing Khat, at house or outside with friends?, Does the practices of this habit with friends affect the family life?, Does he leave his work for practicing this habit?, How does he behave if could not find Khat?, Are his colleagues at work Khat-chewer?

-Questions that describe the behaviour of women having men in their families chewing Khat: included: Does this habit affect your relationship with friends and neighbors?, Have you ever tried to persuade him to withdraw this habit?, Have you seen a physician recommending sick person to withdraw from this habit?, Have you done anything to help him to withdraw this habit? , Have you involved your children or young brothers to persuade the men in the family to withdraw this habit? Have you used the health advices as a way to persuade him to withdraw from this habit? Have you tried before to educate your children or young brothers about 
the risks of this habit to be avoided in future ?, And why?

\section{Ethical consideration}

The research took each participant's permission to audio-record the interview orally with maintaining the participant anonymous for confidentiality. Only one participant refused audio recording, and requested to sign on paper to be included in

\section{A) Demographic data:}

\section{RESULTS}

Demographic data included the age, social status (single or married), number of children, number of family members, income of the family, ownership of garden cultivating Khat trees.

the study documents.

Table (1) Demographic data of the participants (Faifa women):

\begin{tabular}{lll}
\hline Age group & Number & Percentage \% \\
\hline $15-24$ years & 5 & $25 \%$ \\
\hline $25-34$ years & 5 & $25 \%$ \\
\hline$>45$ years & 5 & $25 \%$ \\
\hline Marital status & 5 & $25 \%$ \\
\hline Married & Number & Percentage \% \\
\hline Single & 8 & $40 \%$ \\
\hline Widow & 9 & $45 \%$ \\
\hline Number of children & 3 & $15 \%$ \\
\hline $1-5$ & Number of women & Percentage \% (out of 11 married \\
\hline $6-10$ & & and widows) \\
\hline$>10$ & 7 & $63.6 \%$ \\
\hline Number of family members & 3 & $27.2 \%$ \\
\hline $1-5$ members & 1 & $9 \%$ \\
\hline $6-10$ members & Number of women & Percentage \% \\
\hline $10-20$ members & 7 & $35 \%$ \\
\hline Income in Saudi Riyal & 8 & $40 \%$ \\
\hline Low(<6000) & 5 & $25 \%$ \\
\hline Moderate(7000-15000) & 5 & Percentage \% \\
\hline High(>16000) & 11 & $55 \%$ \\
\hline Owner ship of Khat garden & Number & $25 \%$ \\
\hline Own Khat garden & 19 & $20 \%$ \\
\hline Don't own Khat garden & 1 & Percentage \% \\
\hline
\end{tabular}

- The sample of women is selected to be 5 women in each age group.

- It was found that $40 \%$ of the samples are married, $45 \%$ are single and $15 \%$ are widows.

- The number of married women and widows are 11 women. Seven out of the eleven women $(63.6 \%)$ have $1-5$ children, while $27.2 \%$ of the eleven women have 6-10 children and only one woman $(9 \%)$ has more than 10 children.

- Forty percent of women in this study are living in families with 6-10 members while $25 \%$ of them have families with $10-20$ members. It is noticed that $35 \%$ of women have families composed of 1-5 members.
- It was found that $55 \%$ of women participating in their study have lower income (less than 6000 SR) while $20 \%$ of them have high income (more than 16000SR).

- The majority of women/their families are Khat garden owner (95\%)

\section{B) Knowledge:}

The women have been investigated for their knowledge regarding the following:

- Their knowledge about chewing Khat from the religious point of view.

- Their knowledge about the adverse effects of Khat. 
Table (2) The knowledge of Faifa women about the religious aspects of Chewing Khat and its adverse effects

\begin{tabular}{|c|c|c|c|}
\hline $\begin{array}{l}\text { Item of Knowledge about } \\
\text { chewing Khat }\end{array}$ & $\begin{array}{l}\text { The women knowledge according to what they } \\
\text { said }\end{array}$ & $\begin{array}{l}\text { Number of } \\
\text { women }\end{array}$ & $\begin{array}{l}\text { Percentage of } \\
\text { women }\end{array}$ \\
\hline \multirow[t]{3}{*}{ The religious aspects } & Forbidden & 7 & $35 \%$ \\
\hline & Not forbidden & 8 & $40 \%$ \\
\hline & $\begin{array}{l}\text { Not forbidden but on delaying prayer it becomes } \\
\text { forbidden }\end{array}$ & 5 & $25 \%$ \\
\hline \multirow[t]{8}{*}{ The adverse effects of } & Do not know & 3 & $15 \%$ \\
\hline & $\begin{array}{l}\text { Poisoning, peptic ulcer, liver cirrhosis, dental } \\
\text { caries due to mixing Khat with insecticides }\end{array}$ & 8 & $40 \%$ \\
\hline & Insomnia & 2 & $10 \%$ \\
\hline & $\begin{array}{l}\text { Loss of appetite, loss of weight, weakness of } \\
\text { body and loss of normal liveliness and energy }\end{array}$ & 3 & $15 \%$ \\
\hline & Headache, nervousness, psychological change & 3 & $15 \%$ \\
\hline & Cardiac problem, tumors & 1 & $5 \%$ \\
\hline & Blackening of the skin & 1 & $5 \%$ \\
\hline & Increase rate of smoking & 1 & $5 \%$ \\
\hline
\end{tabular}

Table (2) shows the knowledge of women among the 20 women investigated in this study about the religious aspects and the adverse effects of chewing Khat.

Eight of women (35\%) know that chewing khat is forbidden while $40 \%$ of said it is not forbidden. The others $(25 \%)$ believe that chewing Khat is not forbidden but on delaying prayer it becomes forbidden.

Eighty-five percent of women know that there are adverse effects due to practice of chewing Khat habit. Forty percent of them know that Khat containing insecticide causes poisoning, peptic ulcer, dental caries and liver cirrhosis. Fifteen Percent $(15 \%)$ of women have observed loss of appetite and loss weight, weakness of body, loss normal liveliness and energy in men chewing Khat. Other (15\%) have observed that men chewing Khat suffer from headache, nervousness and psychological changes.

\section{C) Attitudes}

The answers of question to pin down the existing attitudes of women regarding chewing-Khat habit and its withdrawal are classified as follows:

1- Cognitive: thoughts, beliefs and ideas

-Their thoughts about the ways that may help in withdrawal of this habit among Faifa men and the expected challenges

- Their preference for husband, son or brother for living in a city rather than Faifa to withdraw this habit.
-Their thoughts about having a role in reduction /withdrawal of Khat chewing habit that practiced by husband, son or brother and reasons

-Their opinion about who has an influence on men.

2- Affective: feelings or emotions that something evokes e.g. fear, sympathy, hate -Their feeling when their men chew Khat -Their hope for their men to withdraw this habit and reasons.

-Their feeling towards their capability to influence him to change any other behaviour,

3- Conative or behavioural: Tendency or disposition to act in certain ways toward something. Emphasis is on the tendency to act, not the actual acting

-Their level of encouragement of the continuous governmental order for removal of Khat trees and reasons

-Their tendency for influencing son or young brother who has not yet started this habit to prevent them from practicing. 
Table (3) Cognitive attitudes of Faifa women regarding Khat- Chewing Habit

\begin{tabular}{llll}
\hline $\begin{array}{l}\text { Item of cognitive } \\
\text { attitude towards }\end{array}$ & $\begin{array}{l}\text { Cognitive attitudes of women according to what } \\
\text { they said }\end{array}$ & $\begin{array}{l}\text { Number } \\
\text { of women }\end{array}$ & $\begin{array}{l}\text { Percentage } \\
\text { of women }\end{array}$
\end{tabular}

Khat-chewing Habit

Thoughts about the
ways that may help in
withdrawal of this
habit among Faifa
men

\begin{tabular}{llll} 
Establishment of gardens and recreation centers & 9 & $45 \%$ \\
\hline Establishment of football playgrounds and conducting & 11 & $55 \%$
\end{tabular} competitions

\begin{tabular}{lll}
\hline Cutting of the Khat trees completely & 1 & $5 \%$ \\
\hline Cultivate fruits and vegetables instead of Khat & 1 & $5 \%$ \\
\hline Change the environment as transfer to a house in another & 1 & $5 \%$
\end{tabular}

Change the environment as transfer to a house in another $1 \quad 5 \%$ governorate

Expected challenges against the suggested ways to withdraw Khat-Chewing Habit among Faifa men

Men may use playgrounds and recreation centers to gather 3 $15 \%$ with friends for chewing Khat

If cut Khat trees; men will obtain Khat from Yemen which $115 \%$ may be contaminated with insecticides

The substitutes are not of benefit with men having Khat $1 \quad 5 \%$ chewing habit. It may be of benefit with men who did not start this habit

Alternatives may be of benefit in decreasing the practice of $1 \quad 5 \%$

Khat chewing habit but not complete withdrawal

No benefit of any alternative as it is a habit inherited from $1 \quad 5 \%$ generation to the other

\begin{tabular}{|c|c|c|c|}
\hline \multirow{3}{*}{$\begin{array}{l}\text { Preference to transfer } \\
\text { men to another city } \\
\text { rather than Faifa to } \\
\text { withdraw Khat - } \\
\text { chewing habit }\end{array}$} & Prefer transfer to another city & 9 & $45 \%$ \\
\hline & $\begin{array}{l}\text { Do not prefer transfer to another city mainly for emotional } \\
\text { reasons related either to the family or the place of Faifa }\end{array}$ & 11 & $55 \%$ \\
\hline & No comment & 1 & $5 \%$ \\
\hline \multirow{7}{*}{$\begin{array}{l}\text { Thoughts about } \\
\text { having a role in } \\
\text { reduction /withdrawal } \\
\text { of Khat chewing habit } \\
\text { that practiced by } \\
\text { husband, son or } \\
\text { brother and reasons }\end{array}$} & $\begin{array}{l}\text { Women think they have a role to help their sons to withdraw } \\
\text { this habit }\end{array}$ & 3 & $15 \%$ \\
\hline & Women who think they do not have a role because: & 16 & $80 \%$ \\
\hline & Men do not respond to their advices & 9 & $45 \%$ \\
\hline & Men know all the adverse effects but cannot stop & 3 & $15 \%$ \\
\hline & It is a very old tradition that could not be withdrawn & 1 & $5 \%$ \\
\hline & No reason & 3 & $15 \%$ \\
\hline & Women may have a role & 1 & $5 \%$ \\
\hline \multirow{5}{*}{$\begin{array}{l}\text { Opinions on who have } \\
\text { the influence on men } \\
\text { to withdraw Khat- } \\
\text { chewing habit }\end{array}$} & I do not know & 5 & $25 \%$ \\
\hline & No body & 8 & $40 \%$ \\
\hline & Father & 2 & $10 \%$ \\
\hline & Mother & 4 & $20 \%$ \\
\hline & Friend & 1 & $5 \%$ \\
\hline
\end{tabular}

Table (3) shows the cognitive attitudes of women towards Khat chewing habit. About the possible alternatives that may help in withdrawal of Khat chewing habit; women said: establishment of gardens and recreation centers $(45 \%)$, establishment of football play grounds and conducting competitions (55\%), cutting the plant completely (5\%), cultivating fruits and vegetables as alternative to Khat plant $(5 \%)$ and changing the environment $(5 \%)$.

Regarding the challenges against the suggested ways to withdraw Khat chewing habit, $15 \%$ mentioned that men may use gardens and playgrounds for gathering with friends to chew Khat, obtaining contaminated
Khat from Yemen on cutting Khat trees in Faifa, (5\%), the only benefit of these alternatives is with men who did not start this habit with failure with who practice it, (5\%). The added, these alternatives will contribute in reduction of practicing Khat chewing habit, but not absolute withdrawal (5\%) as this habit is inherited and transfer from a generation to the other $(5 \%)$.

Forty five percent (45\%) of women prefer that their men to transfer to another city to withdraw Khat chewing habit. They noticed that in summer holidays and during the family travel to other cities or countries, men enjoy recreation with their families and forget this habit. They mentioned also that this might be 
due to despair of finding Khat plant or due to presence of alternatives for enjoyment. However, 11women (55\%) have refused the idea of transferring to another city for withdrawal of Khat chewing habit. Two women attributed that for emotional reasons of not leaving their brother or son to live away, or leaving Faifa.

Sixteen women $(80 \%)$ think that they have no role in withdrawal of this habit. Nine of those women (9) (45\%) said that men do not respond to women in this point. Three of them (15\%) said that they do not have a role because men know all the adverse effects but unable to withdraw this habit. The last one (5\%) said that this is a traditional habit and not easy to get rid of it. The women who think that they have a role are 3 only (15\%) as they mentioned that they advised their sons to stop this habit at the beginning of practicing this habit and they responded well.

In this study, $25 \%$ of the 20 women do not know who can influence men to get rid of this habit while $40 \%$ of them feel that nobody can influence them. The other women felt that there might be an influence by father $(10 \%)$, mother $(20 \%)$ or friend $(5 \%)$.

Table (4) Affective attitudes of Faifa women regarding Khat - Chewing Habit

\begin{tabular}{|c|c|c|c|}
\hline $\begin{array}{l}\text { Item of affective attitude } \\
\text { towards Khat-chewing Habit }\end{array}$ & $\begin{array}{l}\text { Affective attitudes of women according to what } \\
\text { they said }\end{array}$ & Number of women & $\begin{array}{l}\text { Percentage } \\
\text { women }\end{array}$ \\
\hline \multirow{4}{*}{$\begin{array}{l}\text { Feelings when their men } \\
\text { chew Khat }\end{array}$} & Neutral feeling (neither positive nor negative & 8 & $40 \%$ \\
\hline & Negative feeling (upset, disappointed, feeling nausea) & 7 & $35 \%$ \\
\hline & $\begin{array}{l}\text { Negative feeling (afraid and sad on using Khat with } \\
\text { insecticide) }\end{array}$ & 1 & $5 \%$ \\
\hline & Feel the desire and hope to withdraw this habit & 5 & $25 \%$ \\
\hline \multirow{2}{*}{$\begin{array}{l}\text { Their hope for their men to } \\
\text { withdraw Khat-chewing } \\
\text { habit }\end{array}$} & Want their men to withdraw Khat chewing habit & 17 & $85 \%$ \\
\hline & Do not want to withdraw Khat chewing habit & 3 & $15 \%$ \\
\hline \multirow{11}{*}{$\begin{array}{lllr}\text { Reasons } & \text { for } & \text { hope to } \\
\text { withdraw } & \text { Khat } & \text { chewing } \\
\text { habit } & & \end{array}$} & The bad effect on health status & 11 & $55 \%$ \\
\hline & Fear from the bad deterioration of health & 4 & $20 \%$ \\
\hline & Loss of appetite & 3 & $15 \%$ \\
\hline & Insomnia & 1 & $5 \%$ \\
\hline & Agitation & 1 & $5 \%$ \\
\hline & Adverse effects of Khat mixed with insecticides & 1 & $5 \%$ \\
\hline & Effects on religious practices as delaying of prayers & 1 & $5 \%$ \\
\hline & $\begin{array}{l}\text { Effects on the relationship between husband and wife } \\
\text { especially the social activities }\end{array}$ & 2 & $10 \%$ \\
\hline & Loss of money in buying Khat & 4 & $20 \%$ \\
\hline & For the sake of Family and children & 1 & $5 \%$ \\
\hline & Fear from death of Khat mixed with insecticide & 1 & $5 \%$ \\
\hline \multirow{2}{*}{$\begin{array}{l}\text { Reasons for they do not want } \\
\text { to withdraw Khat chewing } \\
\text { habit }\end{array}$} & Not observing any adverse effect for this habit & 3 & $15 \%$ \\
\hline & $\begin{array}{l}\text { If withdraw this habit the husband will spend a long } \\
\text { time with the wife that disturbs her work }\end{array}$ & 2 & $10 \%$ \\
\hline \multirow{2}{*}{$\begin{array}{l}\text { Feeling towards } \text { their } \\
\text { capability to influence men } \\
\text { to change any other } \\
\text { behaviour }\end{array}$} & Feeling able & 15 & $75 \%$ \\
\hline & Feeling unable & 5 & $25 \%$ \\
\hline
\end{tabular}

Table (4) shows the affective attitudes of Faifa women towards the Khat chewing habit. It was found that 8 women $(40 \%)$ have neutral feeling (neither positive nor negative) regarding the habit of chewing Khat. The others feel neutral if men use natural Khat but "afraid and sad" if Khat is contaminated (5\%) or feel with hope to withdraw this habit, $(25 \%)$. Seven women $(35 \%)$ have negative feeling regarding the habit of chewing Khat. The expressions varied from being "upset", "uncomfortable", "too upset" and "feeling nausea"
It was found that 17 out of the 20 women, (85\%) want their men to withdraw this habit due to the following reasons (every woman gives more than one reasons for their will to withdraw this habit): Effect on the health status, fear from deterioration of health, loss of appetite, insomnia, agitation, adverse effects of Khat contaminated with insecticides, effect on the religious practices as delaying prayers, effect on the relationship between the wife and husband especially the social activities as taking the woman for shopping or entertainment, loss of money in 
buying Khat, for the sake of family and children, and fear from death on using Khat with insecticide

It was found that 3 out of 20 women (15\%) do not want to withdraw this habit as they don't observe any adverse effect from this habit. Two of them (10\%) added if her husband stops this habit, she will spend a long time Table (5) Conative attitudes of Faifa women regarding Khat - Chewing Habit

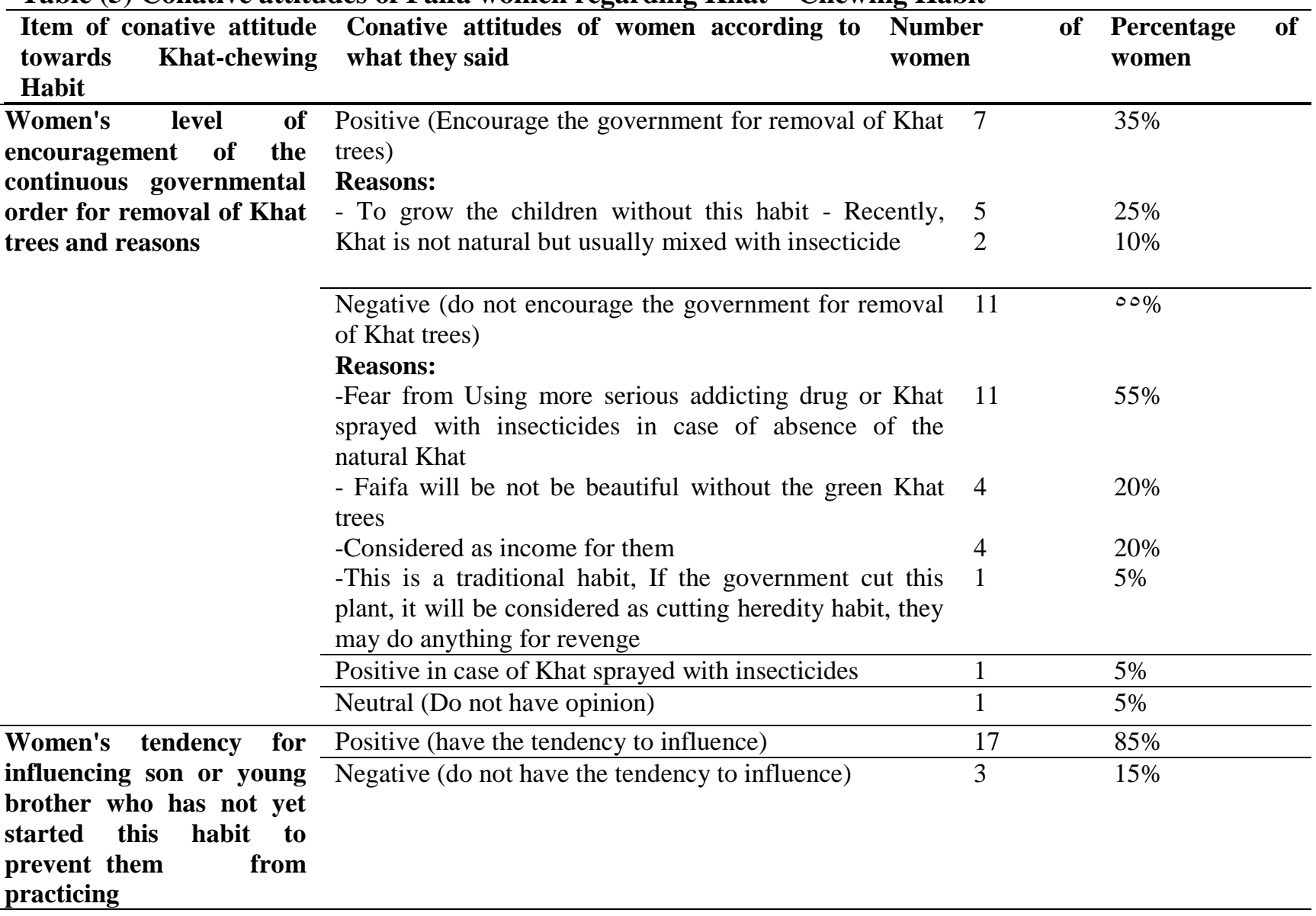

Table (5) shows the conative attitudes of Faifa women towards Khat chewing habit. Fifty five percent of the women in this study (11 women) repel the governmental instructions for removal/cutting Khat trees, because they are afraid of habituation or addiction of other more serious drugs especially for the young adults or taking contaminated Khat coming from Yemen. They consider cultivating and selling Khat plant represent income for them, $(20 \%)$ and Faifa will lose the beautiful green mountains that colored by Khat, $(20 \%)$. Only one of the repellents (5\%) is afraid from any action for vengeance from the side of men if the trees of khat are cut

Thirty -five percent of women encourage governmental instruction for cutting Khat with him that will disturb her for working at home.

In this study it was found 15 women (75\%) feel that they can influence other men's behaviour rather than Khat chewing habit in special circumstances while 5 women said that they feel cannot influence their men to change any other behaviours trees as they want children to grow without grows in a community not using Khat; this will have a great effect to prevent this habit among new generation. The other women (10\%) attributed their support to the instructions as Khat plant is usually contaminated with insecticides that cause adverse effect on health.

In this study 17 women (85\%) have the tendency to play a role to prevent children or young brothers from practicing this habit before they become adult. However, 3 women $(15 \%)$ do not have the tendency to play a role and attributed that to their feeling that the children will imitate their fathers or the older men in the family. 


\section{D) Behaviour}

Behaviour is the way in which one acts or conducts oneself, especially towards others. Questions used to evaluate the behaviour of men chewing Khat from the perspective of women as well as to determine women's behaviour towards Khat chewing habit are included the following:

Questions related to behaviour of men:

- Does he use the natural Khat?

-Does he use the Khat sprayed by the insecticide?

-Does Khat chewing habit influence the user from the religious aspect e.g. delaying prayer, as El-Fajr prayer due to late sleeping?

-Is there any change in his health status or behaviour?

-Where does he spend the time of chewing Khat; at house or outside with friends?

-Does he leave his work for practicing this habit?

-If he doesn't find Khat, how does he behave?

-Are his colleagues at work or friends khatchewer?
Questions related to women behaviour:

-How this habit has influenced your life?

- How this habit influenced the financial status of the family?

-If he practices this habit with friends, has the family life been affected?

-Does this habit affect your relationship with friends and neighbors?

- have you tried before to persuade him to withdraw this habit?

-Have you seen people with disease recommended by the physician to withdraw this habit?

-Have you done anything to him to withdraw this habit?

-Have you tried to persuade your children or young brothers to persuade the men in the family to withdraw this habit?

- Have you used before the health advises as a way to help him to withdraw this habit?

-Have you tried before to educate your children or young brothers that this is a bad habit and must be avoided in future?

Table (6) Reflection of women on the behaviour of men chewing Khat

\begin{tabular}{|c|c|c|c|}
\hline Item of men's behaviour & Description of the behaviour & $\begin{array}{l}\text { Number } \\
\text { of women }\end{array}$ & $\begin{array}{l}\text { Percentage } \\
\text { of women }\end{array}$ \\
\hline \multirow{4}{*}{$\begin{array}{l}\text { Use of natural and/or } \\
\text { Sprayed Khat }\end{array}$} & Use natural Khat & 20 & $100 \%$ \\
\hline & Also use Khat sprayed with insecticides: & 16 & $80 \%$ \\
\hline & -if not finding natural Khat & 4 & $20 \%$ \\
\hline & $\begin{array}{l}\text {-or after passing a long time of spraying the trees of } \\
\text { Khat with insecticide }\end{array}$ & 10 & $50 \%$ \\
\hline \multirow{2}{*}{$\begin{array}{l}\text { Influence of chewing Khat on } \\
\text { religious behaviour }\end{array}$} & No influence on religious behaviour & 8 & $40 \%$ \\
\hline & Have influence on religious behaviour & 12 & $60 \%$ \\
\hline \multirow{2}{*}{$\begin{array}{l}\text { Change of health status or } \\
\text { behaviour due to chewing Khat }\end{array}$} & No change & 16 & $80 \%$ \\
\hline & Some changes & 4 & $20 \%$ \\
\hline \multirow[t]{3}{*}{ Place of chewing Khat } & Home & 10 & $50 \%$ \\
\hline & Outside home with friends & 7 & $35 \%$ \\
\hline & Sometimes at home and other times outside home & 3 & $15 \%$ \\
\hline \multirow{3}{*}{$\begin{array}{l}\text { Effect of chewing Khat on work } \\
\text { of men }\end{array}$} & Promoted & 10 & $50 \%$ \\
\hline & Not promoted & 6 & $30 \%$ \\
\hline & Do not know what is situation in work & 4 & $20 \%$ \\
\hline \multirow{4}{*}{$\begin{array}{l}\text { Behaviour of men on } \\
\text { unavailability of Khat }\end{array}$} & Normal & 11 & $55 \%$ \\
\hline & Nervous and have headache & 6 & $30 \%$ \\
\hline & Sleep & 2 & $10 \%$ \\
\hline & Interferes in house issues & 1 & $5 \%$ \\
\hline \multirow{3}{*}{$\begin{array}{l}\text { Are colleagues or friends of } \\
\text { men chewing Khat }\end{array}$} & Friends are chewing Khat & 14 & $70 \%$ \\
\hline & Do not know & 5 & $25 \%$ \\
\hline & Friends do not chew Khat & 1 & $5 \%$ \\
\hline
\end{tabular}

Table (6) shows the behaviour of men chewing Khat from the perspectives of women in Faifa. All participants (100\%) said that the men in their family use the natural Khat but 16 of them $(80 \%)$ said that they also use the Khat contaminated with insecticides if they don't find natural Khat $(20 \%)$ or after passing along time of being contaminated to avoid hazards $(50 \%)$. 
Regarding the change of religious behaviours; $60 \%$ of women declared that chewing Khat habit has affected the religious behaviour of their men as delaying prayer or not praying $\mathrm{Al}$ Fajr due to delay in sleep.

On the other types of behaviours; $80 \%$ of women denied any change in health or family behaviours among men chewing Khat, but the other $20 \%$ of them observed some health changes on those men. Men spend the time of chewing Khat at home, (50\%), outside home with friends, $(35 \%)$ or at both sites $(15 \%)$.

Regarding behaviour of men at work 10 women $(50 \%)$ said that the men have been

Table (7) Behaviours of Faifa women towards chewing Khat habit

\begin{tabular}{|c|c|c|c|}
\hline Item of women's behaviour & Description of the behaviour & Number of women & $\begin{array}{l}\text { Percentage } \\
\text { of women }\end{array}$ \\
\hline \multirow{4}{*}{$\begin{array}{l}\text { Effect of Khat chewing habit on } \\
\text { women life }\end{array}$} & No effect on life & 14 & $70 \%$ \\
\hline & Has an effect on life: & 6 & $30 \%$ \\
\hline & -weak social life & 3 & $15 \%$ \\
\hline & -feeling lonely & 3 & $15 \%$ \\
\hline \multirow{2}{*}{$\begin{array}{l}\text { Effect of chewing Khat on the } \\
\text { financial status of the family }\end{array}$} & No effect as Khat is available in the trees & 14 & $70 \%$ \\
\hline & $\begin{array}{l}\text { Decrease the financial status due to spending } \\
\text { one third of income on Khat }\end{array}$ & 12 & $60 \%$ \\
\hline \multirow{2}{*}{$\begin{array}{l}\text { Effect of practicing this habit } \\
\text { with friends on family life }\end{array}$} & No effect & 5 & $25 \% \%$ \\
\hline & Adverse effect & 2 & $10 \%$ \\
\hline \multirow{2}{*}{$\begin{array}{l}\text { Effect of practicing } \begin{array}{r}\text { Khat } \\
\text { chewing habit on }\end{array} \text { the } \\
\text { relationships with friends and } \\
\text { neighbors }\end{array}$} & No effect on the social relationships & 13 & $65 \%$ \\
\hline & Negative effect on the social relationships & 7 & $35 \%$ \\
\hline \multirow{2}{*}{$\begin{array}{l}\text { Trials of women to persuade men } \\
\text { to withdraw Khat chewing habit }\end{array}$} & Tried & 10 & $50 \%$ \\
\hline & Never tried & 10 & $50 \%$ \\
\hline \multirow{7}{*}{$\begin{array}{l}\text { Experience with patients advised } \\
\text { by physician to withdraw this } \\
\text { habit }\end{array}$} & $\begin{array}{l}\text { Have seen patients advised to withdraw the } \\
\text { habit: }\end{array}$ & 12 & $60 \%$ \\
\hline & -with liver failure and death & 5 & $25 \%$ \\
\hline & -with heart disease & 3 & $15 \%$ \\
\hline & -Poisoning with insecticide lead to death & 3 & $15 \%$ \\
\hline & -with dental caries & 1 & $5 \%$ \\
\hline & -with peptic ulcer & 1 & $5 \%$ \\
\hline & $\begin{array}{l}\begin{array}{l}\text { Have not seen any patient advised to } \\
\text { withdraw Khat }\end{array} \\
\end{array}$ & 8 & $40 \%$ \\
\hline \multirow[t]{2}{*}{$\begin{array}{l}\text { Doing anything to help men } \\
\text { withdraw Khat chewing habit }\end{array}$} & $\begin{array}{l}\text { Do not do anything to help withdraw this } \\
\text { habit }\end{array}$ & 19 & $95 \% \%$ \\
\hline & $\begin{array}{l}\text { Spend more time with neighbors to reduce the } \\
\text { time for practicing the habit }\end{array}$ & 1 & $5 \%$ \\
\hline \multirow{2}{*}{$\begin{array}{l}\text { Trial to persuade young men to } \\
\text { persuade men practicing Khat - } \\
\text { chewing habit to withdraw it }\end{array}$} & Performed this trial & 2 & $10 \%$ \\
\hline & Never perform this trail & 18 & $90 \%$ \\
\hline \multirow{2}{*}{$\begin{array}{l}\text { Use of health advices to help } \\
\text { withdrawing Khat chewing habit }\end{array}$} & Have used health advices & 12 & $60 \%$ \\
\hline & Never used health advices & 8 & $40 \%$ \\
\hline \multirow{2}{*}{$\begin{array}{l}\text { Trials to educate young children } \\
\text { about this habit as a bad practice }\end{array}$} & Performed this trial & 19 & $95 \%$ \\
\hline & Did not perform this trail & 1 & $5 \%$ \\
\hline
\end{tabular}

Table (7) shows the manner and behaviour of women in Faifa Mountains having men in their families chewing Khat towards this habit. In this study, 14 women $(70 \%)$ denied any effect for Khat chewing habit on their

lives. However, 6 women $(30 \%)$ said that the opposite and explained that as men neither go to shopping, neighbor visits, Alkaabah visit (Omra), (15\%), nor perform important tasks as taking family patient to the hospital promoted in their jobs, while 6 women (30\%) denied this situation. The other 4 women (20\%) do not know what the situation at work is.

For men's behaviour on missing Khat; $55 \%$ of women stated that the men's behaviour is normal, become nervous and complain of headache, $(30 \%)$, sleep $(10 \%)$ or interferes in all the house issues, (5\%).

Seventy percent of women said that $\mathrm{s}$ friends are Khat chewer while $25 \%$ of them do not know and only 1 woman said that friends are not Khat chewer 
because of being busy by Khat chewing habit. The other 3 women (15\%) complain from feeling lonely.

Regarding the effect of Khat chewing habit on the financial status of the family; $70 \%$ of women in this study (14 out of 20 women) denied any effect as their men cultivate Khat in their own garden. However, the other $30 \%$ of them complained of spending about one third of the family income in paying for Khat. Spending the time of chewing Khat for men outside home with friends, $(35 \%)$; women has no effect on the family, $(25 \%)$ while the other $10 \%$ said that it has an adverse effect on the family.

Thirty-five percent of women (7 out of 20 women) said that this habit has a negative effect on the social communication with friends and neighbors as men are busy with Khat Chewing. However, $65 \%$ of women (13 out of 20) said that there is no effect for this habit on the social relationships.

Fifty percent of the sample told that they have tried to persuade men chewing Khat in their families to stop this habit while the other $50 \%$ said that they did not even try. They said that because the men are very sensitive regarding discussion of this issue and never respond to any person giving advice towards the practice, they do not try to make such effort.

In this study that included 20 (twenty) women having men in their families chewing Khat, it was found 12 women $(60 \%)$ have met men advised by the physician to withdraw this habit because Khat chewing may worsen their disease. They have seen patients practicing Khat chewing with insecticide that led to liver failure and death, $(25 \%)$, heart disease, $(15 \%)$ poisoning and death or cancer, (15\%) peptic ulcer $(5 \%)$, or dental caries $(5 \%)$. However, $40 \%$ of women have not seen this case.

Ninety- five percent of women in this study have declared that they did not exert any effort to help men to stop practicing this habit. Forty percent said this is because they feel that men will not respond to their trials. Only one tried to stop this habit by spending more time with their neighbors to delay the time of practicing the habit of chewing Khat.

Only 2 women $(10 \%)$ have pushed children to persuade men chewing Khat to stop this habit.
However, (90\%) did not use this intervention. This is explained by the women, that men may be strongly angry if she behaves like that, or because the father does not like to appear in front of his child as doing something wrong or may be the absence of a strong will to do anything that may contribute to stop this habit.

Sixty percent of women (8 out of 20 women) said that they have used the health advices to help men to decrease practices of Khat chewing habit. They advised with the adverse effects of Khat contaminated with insecticides (30\%), the adverse effects on liver with giving examples of neighbors, (10\%) and threat of losing energy (5\%). However, 12 women $(60 \%)$ said that they don't use health education to advise men to stop chewing Khat.

Ninety - five percent of women (19 out of 20 women) educate the young children in their families that Khat- Chewing habit is a bad habit and should be avoided. Only one woman does not perform this behaviour.

\section{DISCUSSION}

Khat (Catha edulis Forsk) is a natural psychoactive substance that has been chewed for many years in Ethiopia, East Africa and southern Arabian Peninsula (Gebissa, 2010).

The main active (addictive) substances, cathinone and cathine are contained in Khat leaves and are considered prohibited substances as per schedule list of United Nation's International convention on Psychotropic substances (Chappell and Lee, 2010; Laussmann and Meier-Giebing, 2010). The stimulant effect of Khat is more potent (because of cathinone) when the leaves are still fresh and 48 hours after being harvested, the stimulant elements in Khat are converted into a less active potent (cathine) which also has amphetamine-like action (Dhaifalah, 2004). Khat is a mild psychostimulant that increases alertness, enhances mood and reduces the need to sleep. Khat is chewed for its euphoric and stimulating effects, but it has many negative effects on different body systems (Douglas et al., 2011). Khat chewing is associated with gastrointestinal problems such as mouth ulcers, inflammation of esophagus and 
stomach, gum diseases, jaw problems and constipation. Khat chewing is also associated with hypertension, coronary, vasoconstriction and myocardial infarction. Moreover, it is associated with increased susceptibility for stroke and early death. Khat stimulates locomotor and stereotypic behavioural activity, and can induce seizures. Khat chewing can impair driving ability and therefor increase rates of road traffic accidents (Al-Habori, 2005).

Khat chewing is highly prevalent in Yemen ( $82 \%$ among men and $43 \%$ among women) (Numan, 2004). Jazan province of Saudi Arabia lies at the far southwest corner of the country, adjacent to Yemen. This could be the main reason why Khat chewing is widely prevalent in Jazan province as well. Khat chewing has been a major public health problem in Jazan province in Saudi Arabia. In Jazan province the prevalence of chewing Khat is $49 \%$ among general male population but it increases to $62 \%$ in rural areas of Jazan (Elsanosi et al 2011).

Khat chewing is prohibited in Saudi Arabia including Jazan region but its chewing is still increasing at an alarming rate especially among the younger population at schools and institutions of higher learning. To manage this problem, the Saudi government has been trying to control the expansion of chewing, cultivation and trade of Khat. In this regard, the Saudi government has enacted many policies and rules on the prohibition of Khat chewing, however, these strict government policies have failed to eradicate the chewing Khat in Jazan Province (Ageely, 2009).

There are suggestions to develop community programs that help to eradicate this deeply rooted habit (Al Arabia NEWS, 2021). Few studies have been conducted in Jazan focusing on solutions or interventions rather than the governmental regulations; to solve the problem of chewing Khat, (Alsanosy et al., 2013). As an intervention to help in solving this problem, the women having men in their families chewing Khat have been investigated to assess their competencies to help their men to withdraw this habit.

This qualitative study has investigated purposive sample of 20 Saudi women; more than 15 years-old and living in Faifa Mountains, Jazan Governorate, Kingdom of Saudi Arabia. Those women have men among their families practising the habit of chewing Khat. Some demographic data are collected for those women then they were investigated for their competencies (knowledge, attitudes and behaviour) to help their men to withdraw chewing Khat habit.

Demographic Data:

The women's age ranges from 15 to more than 45 years. Fifty five percent of those women were married or widows having children ranges from 1-10. They live in families having members from 1-20; however $75 \%$ of them have families with 1-10 members. Most of them $(95 \%)$ own gardens of Khat however; $55 \%$ of them complain of low income (600 SR monthly). In a study performed in Jazan region, Saudi Arabia to find out the relation between Khat chewing and health related quality of life (Sheikh et al., 2014), it was found that Khat chewers were characterized by low socioeconomic conditions, similar to other types of substance abuse.

Although Khat trading is illegal in Saudi Arabia and since 2006 a new stricter legal system was implemented, it seems to have no effect to stop Khat chewing habit as Khat is easy to be obtained. Faifa area in Jazan is famous for Khat production (Alsanosy et al., 2013).

Knowledge of Women:

Regarding the women's knowledge related to chewing Khat habit; $35 \%$ of them know that chewing khat is forbidden from the religious point of view; while $40 \%$ said it is not forbidden. The others (25\%) believe that chewing Khat is not forbidden but on delaying prayer it becomes forbidden. Saudi Arabia, a sovereign Arab Islamic state where a more fundamentalist Islam is practiced, outlawed khat decades ago (Douglas and Hersi, 2010). This reflects the women's poor knowledge about the religious laws of Khat chewing habit in Saudi Arabia

Regarding the adverse effects of chewing Khat; the majority of women in this study $(95 \%)$ know that there are adverse effects due to practice of chewing Khat habit either due to mixing Khat with insecticide or due to the 
adverse effects of Khat itself. Forty percent of them mentioned that Khat containing insecticide causes poisoning, peptic ulcer, dental caries and liver cirrhosis while (15\%) have observed loss of appetite and loss weight, weakness of body, loss of normal liveliness and energy in men chewing Khat. The Other 3 women (15\%) have observed that men chewing Khat suffer from headache, nervousness and psychological changes. However, three women (15\%) in this study, although they stated that there are hazardous effects due to the habit of chewing Khat; they don't know what the adverse effects of this habit are. It is well documented that Khat has many public health and social problems, (Halbach, 1972). The knowledge on risk factors and predictors is crucial to design prevention programs against Khat chewing habit (Alsanosy et al., 2013).

Attitudes of women:

The cognitive attitudes investigated among women included their thoughts about the ways that may help in withdrawal of this habit among Faifa men and the expected challenges, their preference to transfer men to another city rather than Faifa to withdraw Khat -chewing habit, their thoughts about having a role in reduction /withdrawal of Khat chewing habit that practiced by husband, son or brother and reasons as well as their opinions on who have the influence on men to withdraw Khat-chewing habit

To help in withdrawal of Khat chewing habit; women suggested: establishment of gardens and recreation centers (45\%), establishment of football play grounds and conducting competitions (55\%), cutting the plant completely (5\%) and cultivating fruits and vegetables as alternative to Khat plant $(5 \%)$. The last one $(5 \%)$ mentioned that changing the environment in Faifa to another governorate may help to withdrew this habit. The available alternatives for youth to spend their time are limited in the region. Thus, the options for entertainment, voluntary work, open spaces like parks and playgrounds, clubs, sports and recreational activities are highly needed (Wedegaertner et al., 2010).

The challenges against the previously suggested ways to withdraw the are the use of gardens and playgrounds as places for gathering with friends for chewing Khat and obtaining Khat from Yemen on cutting the trees of Khat in Faifa, (5\%). Those suggestions may be helpful with men who are not using Khat but not for those practicing the Khat chewing habit, as stated (5\%). The women in this study believe that Khat chewing habit is deeply rooted and could not absolutely eradicated.

Forty five percent of women think that transfer to another city may help to withdraw Khat chewing habit. However, 11women $(55 \%)$ have refused the idea of transferring to another city for withdrawal of Khat chewing habit either for emotional reasons or feeling home sickness.

About their role to help men to withdraw Khat chewing habit; $80 \%$ of them think that they do not have a role for that. They attributed that to the refusal of men to respond to their advices, (45\%), or men cannot withdraw this habit although they know all the adverse effects, $(20 \%)$. The women who think that they have a role were 3 only (15\%) because of their successful experience with their sons to stop this habit at the beginning of practice. The substance abuse literature found that the parents' attitudes towards their children smoking or abusing drugs are influential factors for adolescent smoking and drug abuse (Harakeh et al., 1992).

In this study, $25 \%$ of the 20 women do not know who can influence men to get rid of this habit while $40 \%$ of them feel that nobody can influence them. The other women felt that there might be an influence by father, mother, or friend. Family factors and backgrounds play an important role in the development of youth behaviour. This family role is very clear in smoking and other substance abuse,

(Madarasova et al., 2005).

The affective attitudes investigated among the women of Faifa included their feelings when their men chew Khat, their hope for their men to withdraw Khat-chewing habit and reasons as well as their feeling towards their capability to influence men to change any other behaviour.

The investigated women have neutral feeling (neither positive nor negative) regarding the 
habit of chewing Khat, (40\%) or felling" afraid and sad" only if Khat is contaminated with insecticide, (5\%), and hoping to withdraw this habit, (25\%). However, $35 \%$ of them have negative feeling regarding the habit of chewing Khat. The expressions varied from being "upset", "uncomfortable", "too upset" and "feeling nausea".

Eighty -five percent of the investigate women want their men to withdraw this habit due to its effect on the health status, fear from deterioration of health, loss of appetite, insomnia, agitation, adverse effects of Khat contaminated with insecticides, effect on the religious practices as delaying prayers, effect on the relationship between the wife and husband especially the social activities, loss of money in buying Khat, and for the sake of family and children. Khat chewing was reported as a main source of family problem that reduces the quality of life of the spouses. This could be explained by the following reasons: First; Khat is usually chewed in group sessions and takes a long time (more than 6 hour per session) of chewing with peers or friends. This habit routinely causes the chewer to neglect their families and consequently prompts conflict with the spouse. Second; money spent on Khat purchase can also cause conflict between spouses. Third; sleeping problems that are often associated with khat chewing severely affect working hours and consequently reduces family income. Finally, the emotional instability, mood swings and the bad temper associated with Khat chewing can cause the chewer to be violent and aggressive towards the spouse (Wedegaertner et al., 2010).

Opposite to that, it was found that 3 out of 20 women $(15 \%)$ do not want to withdraw this habit as they don't observe any adverse effect from this habit. Two of them (10\%) added if her husband stops this habit, she will spend a long time with him that will disturb her for finishing her house work. In a study among Yemeni Khat consumers, they argue that Khat improves relationships in Yemeni society and it is the best way to spend one's time, leads to relief of social and mental stress and improve sexual experience (Wedegaertner et al., 2010). Social acceptability of Khat chewing and socialization of this habit increase the likelihood of adolescents adopting this behaviour (Alsanosy et al., 2013).

In this study it was found 15 women (75\%) feel that they can influence any men's other behaviour rather than Khat chewing habit in special circumstances while 5 women said that they feel cannot influence their men in any other behaviours. This may be explained as Khat chewing is a common habit among the population in Jazan region including Faifa Mountains as adjacent to Yemen and richness with Khat trees. The practice is deeply rooted in the socio-cultural traditions of all segments of Jazan region, including school students, (Milaat et al., 2006).

The conative attitudes investigated among Faifa women included the level of encouragement of the continuous governmental order for removal of Khat trees and reasons as well as their tendency for influencing son or young brother who has not yet started this habit to prevent them from practicing.

Eleven women (55\%) repel the governmental instructions for removal of Khat trees, because they are afraid of habituation or addiction for another more serious drug as alternative for Khat especially for young adults, or going to take Khat coming from Yemen which is usually contaminated with insecticides. They refuse the governmental instructions to cut the plant because cultivating and selling Khat plant represent income for them (20\%), losing the beauty of Faifa green plant $(20 \%)$, or fear of men revenge $(5 \%)$.

Women who encourage governmental instruction $(35 \%)$; attributed that to their will to let their children to grow without this habit and to avoid Khat contaminated with insecticides. As socio-economic status has often been characterized as a root cause of health inequalities and health risk factors; primary prevention activities such as law enforcement efforts and community-based interventions focusing on social networking and improving socioeconomic conditions may help change khat chewing behaviour or prevent potential Khat users from indulging in Khat chewing (Gallea and Vlahov, 2002). 
Law enforcement interventions are among the most frequent policies to fight with substance abuse habits; however, the intervention can stop the spread of Khat chewing from lower socio-economic class to higher socioeconomic class (Sheikh et al., 2014). The perspectives of women living in Faifa should be considered in designing program to eradicate Khat chewing habits as they are involved in the life there and realize to a great extent what are the obstacles of this habit withdrawal.

It is clear that women have the tendency to play a role in preventing their children to practice this habit by $85 \%$ of them; however, 3 women (15\%) do not have the tendency to play a role because they feel that children will imitate their fathers or the older men in the family.

Reflection of women on the behaviour of men chewing Khat was investigated according to the following items: Use of natural and/or sprayed Khat, effect of chewing Khat on religious behaviour, change of health status or behaviour due to chewing Khat, place of chewing Khat, effect of chewing Khat on work of men, behaviour of men on unavailability of Khat and if colleagues or friends of men are chewing Khat.

All participants $(100 \%)$ said that the men in their families use the natural Khat but $80 \%$ said that they also use Khat contaminated with insecticides if they don't find natural Khat $(20 \%)$ or after passing along time of spraying with insecticide (50\%). Faifa mountain area is famous for Khat production. The government prohibits the expansion of Khat cultivation in Faifa Mountain and established Faifa development Authority since 1978 under the supervision of the Ministry of Interior to control Khat cultivation and support farmers to replace Khat with alternative crops such as fruits and coffee trees (Ageely, 2009). However, Khat is still cultivated in Faifa and strengthening of mechanisms for law enforcement is needed to minimize the availability of Khat in the community (Alsanosy et al., 2013). Women noticed that chewing Khat habit has affected the religious behaviour of their men, $(60 \%)$ but not the health behaviour or condition,
(80\%). This finding is supported by the studies that indicated societal and mental health burden due to Khat chewing is comparatively higher than its physical harm,

(Dhadphale and Omolo, 1988; Brenneisen et al., 2012). Fifty percent of women said that their men spend the time of chewing Khat at home while $35 \%$ are outside home with friends. The other $15 \%$ spend the time of Khat chewing at the two places. About the effect of Khat chewing on men's work $50 \%$ of women did not notice any effect; however, the other $50 \%$ said that the men have been promoted in their jobs. In the study run in Jazan region among Khat chewers (Sheikh et al., 2014), it was found that more than $70 \%$ of Khat chewers were younger than 35 years, and the unemployment rate was $62 \%$ among Khat chewers. This result complies with other studies which have reported that excessive Khat use is associated with reduced productivity and risk of unemployment because Khat reduces motivation of work and increases the occurrence of work absenteeism, (Elmi, 1983; Klein, 2008).

Fifty-five percent of women stated that the men's behaviour is normal even with missing Khat, others noticed men's nervousness and complaints of headache $(30 \%)$, sleepiness $(10 \%)$ or disturbing home $(5 \%)$ if do not find Khat. There are conflicting opinions regarding the existence of a withdrawal syndrome for Khat using. Physical withdrawal symptoms are documented, including lassitude, anergia, nightmares and slight trembling, which appear several days after ceasing to chew. Depressive disorder, sedation and hypotension are sometimes seen after withdrawal of khat (Alem et al., 1999).

Seventy percent of women said that men's friends are Khat chewer while $25 \%$ of them do not know. In a study run in Jazan region for Khat chewing habit among school students; it was found that peer influence was an important factor in students' practice of substance use (Alsanosy et al., 2013). Previous studies have found that friends' and parents' use of substances is strongly associated with the use of substances among students, indicating the influence of peer 
pressure (Rozi et al., 2007; Rapeah et al., 2008).

Behaviour of women towards Khat chewing habit has been investigated for the following items: Effect of Khat chewing habit on women life, financial status of the family, family life, and relationships with friends and neighbors. Trials of women themselves, use young men in the family, use the health advices or doing anything to help/persuade men to withdraw Khat chewing habit is investigated. Also, the women's experience with patients advised by physician to withdraw this habit and their trials to educate young children about this habit as a bad practice is investigated.

In this study, women denied any effect from Khat chewing habit on their lives, $(70 \%)$, while $30 \%$ stated that their family lives have been affected. Also they denied any effect of this habit on the financial status of the family as they own Khat tress gardens, (70\%). However, $30 \%$ of them said the opposite as men spend about one third of the family income in paying for Khat. As 35\% of women said that men spend the time of chewing Khat outside home with friends; $25 \%$ said that this practice has no effect on the family while the other $10 \%$ said that it has an adverse effect on the family. Thirty-five percent of women stated that that this habit has a negative effect on the social communication with friends and neighbors, however, $65 \%$ of women denied any bad effect on the social relationships. In the study for finding the relation between Khat chewing and health related quality of life in Jazan region (Sheikh et al., 2014). it was found that Khat is associated with lower quality of life and lower socio-economic status. Therefore, intervention measures are indicated to manage this problem.

The practices of women regarding helping their men to withdraw this habit are too little.

Fifty percent of the women sample told that they have tried to persuade men chewing Khat in their families to stop this habit while the other $50 \%$ said that they did not try. They said that because the men are very sensitive regarding discussion of this issue and never respond to any person giving advice towards the practice, they do not try to make such effort.

About their experience with patients chewing Khat; who have been advised by the physician to stop this habit; it was found that $60 \%$ of them have seen men advised by doctor to withdraw this habit because Khat chewing may worsen their disease. They have seen patients practicing chewing Khat with liver failure and death due to sprayed Khat (25\%), heart disease $(15 \%)$ and insecticides poisoning due to sprayed Khat (15\%), dental caries $(5 \%)$ and peptic ulcer (5\%). However, $40 \%$ of women have not seen a patient practicing Khat chewing. However, 95\% of women in this study have declared that they did not exert any effort to stop practicing this habit by their men. Forty percent attributed that to their feeling that men will not respond to their trials. Only one of them tried to stop this habit by spending more time with their neighbors to delay the time of practicing the habit of chewing Khat. In this study, it was found that only 2 women (10\%) have persuaded a small child to educate adult man chewing Khat to try persuading him to decrease this habit. However, the majority of women (18 women) (90\%) did not use this intervention. This is explained by the women, that men may be strongly angry if she does that, or because the father does not like to appear in front of his child as doing something wrong or may be the absence of a strong will to do anything that may contribute to decrease this habit.

Sixty percent of women said that they have used the health advices to help men to decrease practices of Khat chewing habit. They mentioned the effects of Khat mixed with insecticide which leads to chronic diseases and death and the adverse effects of Khat on liver and used the evidence with a neighbor who had liver cirrhosis and referred to a hospital in Riyadh. One of them added that she used the information of losing energy as a way to of health advice to reduce the habit. However, 12 women $(60 \%)$ said that they don't use health education to advise men chewing Khat.

In a study of about women's career advancement through mentoring and 
networking in Saudi Arabia and UK; the findings revealed that women in SA and the UK have different concepts of both mentoring and networking, and this relates to the cultures in the two countries. Women in SA associated mentoring and networking with their family members rather than their professional networks. In contrast, the women in the UK conceptualized mentoring and networking as something that took place, either formally or informally, in the workplace or through their wider professional networks (Abalkhail and Barbara, 2015).

In a study for investigating the impact of socio-economic changes on the traditional role of women in Saudi Arabia, it was found that there are major social and cultural changes reflected in family structure and marriage styles, as well as in the rising number of educated women. Despite these changes, however, no significant modification in the traditional role of women was observed. This is believed to be because employment opportunities for women in the modem sectors of the economy remain extremely limited while the traditional economic contributions of women have become undervalued (Alsuwaigh, 1989).

The grand vision behind Vision 2030 is to transform the Saudi economy from an oil dependent economy to a post-oil economy, thus to place the Saudi economy on a more solid and economically sustainable footing. According to official statistics, Saudi Arabia has a total population of approximately 32 million people. Of these 12 million are migrants. Of these 32 million, approximately 11 million are employed i.e. hold a job that pays a salary. Of the employed 5 mills are Saudis and 6 mills are migrants. Of the employed 5 mill Saudis, only 1 mill is women. Phrased differently, out of the around 20 mill. Saudi nationals only $40 \%$ of the men are in employment and only $10 \%$ of the women. By international standards these numbers are extremely low. The most visible initiative taken to bring women into the job market and change their status in society was the decree issued by King Salman in September 2017 which reinstated the right of women to drive. This will take effect on the
24 June 2018, (Hvidt, 2018). This situation the major change running in the Saudi Society that should be reflected on the attitudes and behaviours of women to be strengthened for being a decision maker in the family and discard the negative attitudes and behaviours.

Ninety - five percent of women educate the young children that Khat- Chewing habit is a wrong habit and should be avoided.

\section{CONCLUSION}

Although women realize the adverse effects of Khat chewing habit, they do not feel a bad effect on their lives either socially or economically. However, they have a will to stop this habit but do not exert a considerable effort except some education with the children in their families for prevention of this habit.

\section{RECOMMENDATIONS}

This may give place for further studies about how to stop the Khat chewing habit rather than influence of women on men in Faifa Mountains. The attitudes of women should be developed for strengthening of their behaviour towards helping men to eradicate the Khat chewing habit, especially in this era that pushing women in all fields to be a wheel for better movement.

\section{Study limitation:}

Although the information collected in this research is rich and fruitful; the results cannot be generalized as the sample of women is purposive.

\section{ACKNOWLEDGEMENTS}

I would like to acknowledge Prof. Mona El Mahdy, Professor of Community Medicine, Faculty of Medicine, Jazan University for her meticulous scientific review especially the methodologies as well as. Dr. Dina El Kordy for her assistance in editing services.

\section{REFERENCES}

1. Abalkhail, J. and Barbara, A. (2015): Women's career advancement: mentoring and networking in Saudi Arabia and the UK; Human resource Develop. Intern., 18 (2): 153168.

2. Abdelwahab, S. Alsanosy, R. Taha M. and Mohan S. (2018): Khat induced toxicity: Role on its modulating effects on inflammation and oxidative stability. Hindawi Biomed. Res. Intern.; 1- 7 
3. Ageely, H. (2009): Prevelence of Khat chewing in college and secondry (high) school students of Jazan region, Saudi Arabia. Ham Reduct J., 6: 11 .

4. Al Arabia NEWS (2021): Exploring Saudi Arabia: The Faifa Mountains known for beauty and agriculture, 1-4.

5. Alem, A. Kebede, D. and Kullgren, G. (1999): The prevalence and sociodemographic correlates of khat chewing in Butajira, Ethiopia. Acta Psych. Scand. Suppl., 100: 84-91.

6. Al-Habori, M. (2005): The potential adverse effects of habitual use of Catha edulis (Khat). Expert Opin. Drug Saf.; 4: 1145-1154.

7. Alsanosy, R. Mahfouz, M. and Gaffar, A. (2013): Khat chewing among students of Higher Education in Jazan region, Saudi Arabia: Prevelence, pattern and related factors. Biomed. Res. int., 487(232): 1-12.

8. Alsuwaigh, S. (1989): Women in transition: The case of Saudi Arabia. J. Comp. Fam. Stud., 20 (1): 67-78.

9. Andrews, T. and Scott, H. (2013): What is Grounded Theory - Grounded Theory. Online Support. GT Res.

10. Brenneisen, R. Fisch, H. Koelbing, U. Geisshusler, S and Kalix, P. (2012): Amphetamine-like effects in humans of the Khat alkaloid cathinone. Br. J. Clin. Pharmacol., 30: 825-828.

11. Chappell, J. and Lee, M. (2010): Cathinone preservation in Khat evidence via drying. Forensic Sci. Int.; 195: 108-120.

12. Dhadphale, M. and Omolo, O. (1988): Psyciatric morbidity among Khat chewers. East Afr., Med. J., 65: 355-359.

13. Dhaifalah, S. (2004): Khat habit and its health effect. Anatural amphetamine. Biomed. Pap. Med. Fac. Univ. Palcly Olomuc Czech Repub., 148: 11-15.

14. Douglas, H. and Hersi, A. (2010): Khat and Islamic legal perspectives, Issues for consideration. J. Legal Pluralism Unofficial Law: 95-114.

15. Douglas, H. Boyle, M. and Lintzeris, N. (2011): The health impacts of Khat: a qualitative study among Somali-Australians. Med. J. Aust.; 195: 666-669.

16. Elmi, AS. (1983): The chewing of Khat in Somalia. J. Ethnopharmacol., 8: 163-176.

17. Elsanosi, R. Bani, I. Ageely, H. Milaat, W. El-Najjar, M. Makeen, A and Yagoob, U. (2011): Socio-medical problem of the habituation of Khat chewing in Jazan region in southern Saudi Arabia. Eur. J. Sci. Res., 63: 122-133.

18. Gallea, S. and Vlahov, D. (2002): Social determinants and health of drug users: socioeconomic status, homelessness and incarceration. Pub. Health Rep., 117: S135.

19. Gebissa, E. (2010): Khat in the Horn of Africa: historical perspectives and current trends. J. Ethnopharmacol.; 132: 607-614.

20. Halbach, H. (1972): Medical aspects of the chewing Khat leaves. Bulletin of the World Health Org., 47(1): 21-29.

21. Harakeh, Z. Scholte, R. Vermulst, A. de Vries H. and Engels, R. (1992): Parental factors and adolescents' smoking behaviour: an extension of the theory implications for substance abuse prevention. Psychol. Bull, 112: 64-105.

22. Hvidt, M. (2018): The new role of women in the new Saudi Arabian economy. Videnscenter om det moderne Mellem $\phi s t e n$ Publication date.

23. Kalix, P. and Branden, O. (1985): Pharmacological aspects of the chewing Khat leaves. Pharmacol. Rev., 37(2): 149-164.

24. Klein, A. (2008): Khat in the neighborhoodlocal government responses to Khat use in London community. Subst. Use Misuse, 43: 819-831.

25. Laussmann, T. and Meier-Giebing S. (2010): Forensic Analysis of hallucinogenic mushrooms and Khat (Catha edulis Forsk) using cation-exchange liquid chromatography. Forensic Sci. Int.; 195: 160-164.

26. Madarasova, A. Stewart, R. van Dijk, J. Orosova, O. Groorhoff, Jw. and Post, D. (2005): Influence of socio-economic status, parents and peers on smoking behaviour of adolescents. Eur. Addict. Res.; 11: 204-209.

27. Mahfouz, M. Rahim, B. Solan, Y. Makeen A. and Alsanosy, R. (2015): Khat Chewing Habits in population of the Jazan region, Saudi Arabia: Prevelance and associated Factors. PLoS One; 10 (8): 1-13.

28. Mega A. and Dabe, E. (2017): Khat (Cath Edulis) as a risk factor for cardiovascular disorders: Systematic review and metaanlaysis. Open Cardiovas. Med. J.; l (11): 146155.

29. Milaat, A. Bani, I. and El-Naggar, M. (2006): Assessment of health risk factors and social problems associated with Khat use in Jazan region. Res.Rep., King AbdulAziz Uni., KSA.

30. Miller, S. Fiellin, D. Rosenthal R. and Saitz R. (2019): The ASAM Principles of Addiction 
Medicine" $6^{\text {th }}$ ed., Philadelphia, Wolters Kluwer.

31. Miretu, A. Nhunzi, C. Fekadu, A. Norton S. and Teferra, S. (2019): Definition and Validity of the Construct Problematic Khat Use; A Systematic Review. Euro. Addiction Res., 25 (4), 161-172.

32. National Institute of Diabetes and digestive and Kidney diseases (2018): Liver Tox. Clin. Res. Info. Drug-Used Liver Inj.

33. Numan, N. (2004): Exploration of adverse psychological symptoms in Yemini Khat users by the Symptoms Checklist-90 (SCL). Addict.; 99: 61-65.

34. Rapeah, M. Munirah, Y. Latifah, O. Faizah, K. and Norsimah, S. (2008): Factors influencing smoking behaviours among adolescents in Kuantan district. Annal. Dent. Univ. Malaya, 15: 77-81.
35. Rozi, S. Butt, ZA and Akhtar S. (2007): Correlates of cigarettes smoking among male college students in Karachi, Pakistan: BMC Pub. Health, 7: 312.

36. Sheikh, K. El-Setouhy, M. Yagoub, U. and Ahmed Z. (2014): Khat chewing and health related quality of life: Cross-sectional study in Jazan region, Kingdom of Saudi Arabia. Health and Quality of Life Outcomes, 12 (44): 1-10.

37. Wedegaertner, F. Al-Warith, H. Hillemacher, T. Te Wildt, B. Shneider, U. Bleich, S. and Breitmeier, D. (2010): Motives for Khat use and abstinenece in Yemen- a gender perspective. BMC, Pub. Health, 10: 735. 
أجريت هذه الدر اسة على • ب امر أة فوق 10 سنة من النساء اللاتي يقمن في جبال فيفاء .النتائج الواضحة في الدر اسة ان \%ج\% من النساء يعتقدن أن القات غير محرم ،0\%\% يؤكدن بأضرار القات ملخصة في آثاره الجانبية على القلب و الكبد .خمسة وثمانون

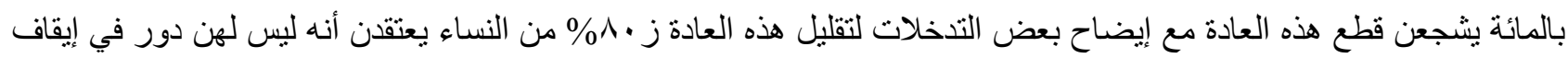

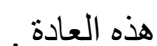

معظم النساء ذكرن أن هذه العادة لاتؤثر على العمل و لا دين الرجل ولا تصر فاته أو الحالة المادية أو الاجتماعية

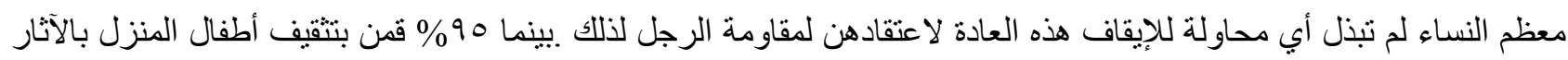
الجانبية لهذه العادة و أنها عادة سيئة . من النساء يعترفن بأضر ار عادة مضغ القات ولكنهن لا يشعرن بتأثير سيء على حياتهن الاجتماعية والاقتصادية ومع هذا فإنهن ير غين في إقلاع الرجال عن هذه العادة لكن لم يعطلن جهد و اضح إلا تثقيف أطفال المنزل لتجنب هذه العادة هذا يرشدنا لاراسات قادمة كيف يتم قطع عادة مضغ القات ليس عن طريق نأثير النساء على الرجال في جبال فيفاء . 